\title{
Dopamine Modulates the Activity of Sensory Hair Cells
}

\author{
(C) Cecilia Toro, Josef G. Trapani, Itallia Pacentine, Reo Maeda, Lavinia Sheets, Weike Mo, and Teresa Nicolson \\ Oregon Hearing Research Center and the Vollum Institute, Oregon Health and Science University, Portland, Oregon 97239
}

The senses of hearing and balance are subject to modulation by efferent signaling, including the release of dopamine (DA). How DA influences the activity of the auditory and vestibular systems and its site of action are not well understood. Here we show that dopaminergic efferent fibers innervate the acousticolateralis epithelium of the zebrafish during development but do not directly form synapses with hair cells. However, a member of the D1-like receptor family, D1b, tightly localizes to ribbon synapses in inner ear and lateral-line hair cells. To assess modulation of hair-cell activity, we reversibly activated or inhibited D1-like receptors (D1Rs) in lateral-line hair cells. In extracellular recordings from hair cells, we observed that D1R agonist SKF-38393 increased microphonic potentials, whereas D1R antagonist SCH-23390 decreased microphonic potentials. Using ratiometric calcium imaging, we found that increased D1R activity resulted in larger calcium transients in hair cells. The increase of intracellular calcium requires Cav1.3a channels, as a Cavl calcium channel antagonist, isradipine, blocked the increase in calcium transients elicited by the agonist SKF-38393. Collectively, our results suggest that DA is released in a paracrine fashion and acts at ribbon synapses, likely enhancing the activity of presynaptic Cav1.3a channels and thereby increasing neurotransmission.

Key words: D1 receptor; dopamine; efferents; hair cell; lateral-line organ; zebrafish

\section{Significance Statement}

The neurotransmitter dopamine acts in a paracrine fashion (diffusion over a short distance) in several tissues and bodily organs, influencing and regulating their activity. The cellular target and mechanism of the action of dopamine in mechanosensory organs, such as the inner ear and lateral-line organ, is not clearly understood. Here we demonstrate that dopamine receptors are present in sensory hair cells at synaptic sites that are required for signaling to the brain. When nearby neurons release dopamine, activation of the dopamine receptors increases the activity of these mechanosensitive cells. The mechanism of dopamine activation requires voltage-gated calcium channels that are also present at hair-cell synapses.

\section{Introduction}

Information about auditory/vestibular stimuli is transmitted from the peripheral sensory epithelium of the inner ear to the brain by ascending afferent neurons. Concurrently, signaling by the inner ear is modulated by descending efferent neurons from the brain. Although efferent fibers likely outnumber afferent fi-

Received April 30, 2015; revised 0ct. 6, 2015; accepted Nov. 11, 2015.

Author contributions: C.T., J.G.T., R.M., W.M., and T.N. designed research; C.T., J.G.T., I.P., R.M., and W.M. performed research; L.S. contributed unpublished reagents/analytic tools; C.T., J.G.T., I.P., R.M., and W.M. analyzed data; C.T., J.G.T., and T.N. wrote the paper.

This study was supported in part by National Institutes of Health T32 DK007680 and F32 DC013936 to C.T., National Institutes of Health R01 DC013531 to T.N., and Howard Hughes Medical Institute funding.

The authors declare no competing financial interests.

Correspondence should be addressed to Dr. Teresa Nicolson, Oregon Hearing Research Center and Vollum Institute, 3181 SW Sam Jackson Park Road, Oregon Health and Science University, Portland, OR 97239. E-mail: nicolson@ohsu.edu.

C. Toro's present address: Linfield College, McMinnville, Oregon.

J. G. Trapani's present address: Amherst College, Amherst, Massachusetts.

L. Sheets' present address: Department of Otology and Laryngology, Harvard Medical School, Boston, Massachusetts; and Eaton-Peabody Laboratory, Massachusetts Eye and Ear Infirmary, Boston, Massachusetts.

DOI:10.1523/JNEUROSCI.1691-15.2015

Copyright $\odot 2015$ the authors $\quad 0270-6474 / 15 / 3516494-10 \$ 15.00 / 0$ bers, they have received much less attention and are less well understood (Schofield, 2011). The presence of dopamine (DA) in the inner ear suggests that DA has a modulatory role within the sensory epithelium (Gil-Loyzaga and Parés-Herbute, 1989). However, the physiological effects of DA on cellular targets in the auditory/vestibular system remain poorly understood. Several studies have probed the role of DA in the inner ear by seeking to identify the postsynaptic partner of dopaminergic efferents. However, these studies have drawn a complex scenario by providing evidence for direct innervation by dopaminergic efferents of both afferent fibers (Eybalin et al., 1993; Karadaghy et al., 1997; Darrow et al., 2006; Inoue et al., 2006; Niu and Canlon, 2006; Maison et al., 2012) and hair cells (Drescher et al., 2010). In addition to these two postsynaptic targets, the type of DA receptor in the inner ear appears to include both the D1-like and D2like receptor subfamilies that have opposing effects on cAMP signaling (Beaulieu and Gainetdinov, 2011).

In mammals, the specific effect of DA on the output of primary auditory tissue has been studied by measuring the compound action potential (CAP), which represents the combined activity of all cochlear afferents. These experiments suggest a fa- 
A

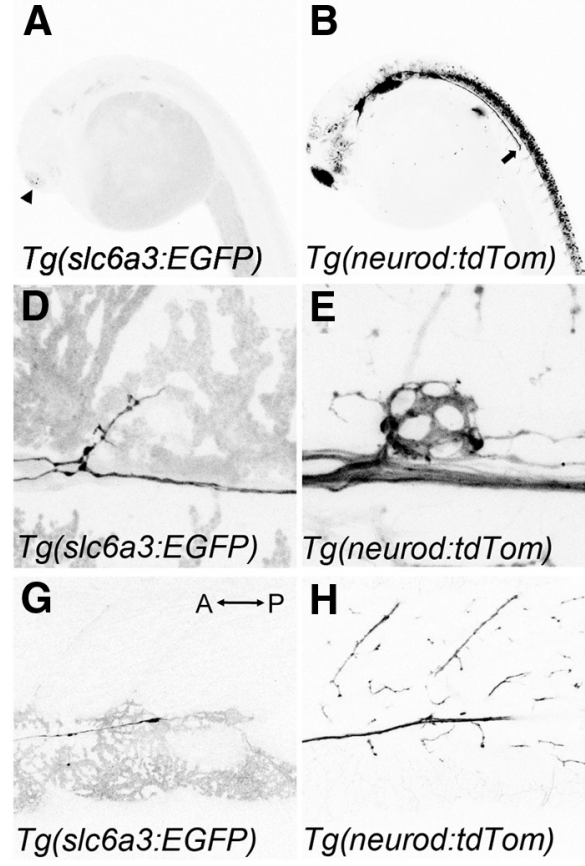

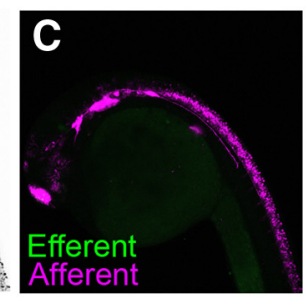
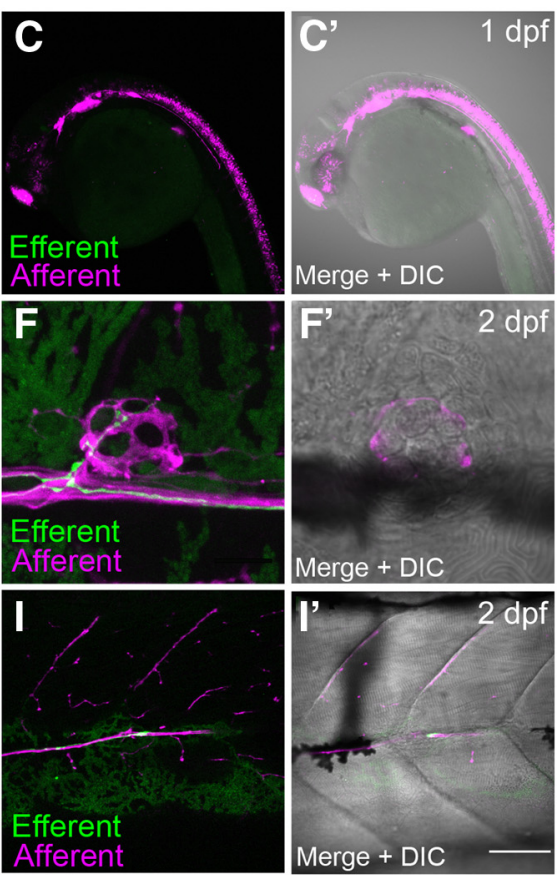

Figure 1. Innervation of lateral-line hair cells by dopaminergic fibers during early development. Efferent and afferent fibers were visualized in developing embryos by crossing two transgenic lines: $\mathrm{Tg}$ (slc6a3:EGFP) and $\mathrm{Tg}$ (neurod:tdTomato). A, Faint GFP expression is detected within the head at $1 \mathrm{dpf}$ (arrowhead). $\boldsymbol{B}$, tdTomato-positive fibers representing cranial and lateral-line afferent neurons at $1 \mathrm{dpf}$. Arrow indicates the lateral-line nerve extending down the trunk. $\boldsymbol{C}$, Overlays of $\boldsymbol{A}$ (green) and $\boldsymbol{B}$ (magenta). $\boldsymbol{C}^{\prime}$, Overlay that includes the corresponding DIC image. D, Presence of a GFP-positive efferent fiber innervating the first trunk neuromast (L1) near the swim bladder at $2 \mathrm{dpf}$. $\boldsymbol{E}$, Corresponding afferent fibers for the neuromast in $\boldsymbol{D}$. $\boldsymbol{F}, \boldsymbol{F}^{\prime}$, Overlays of $\boldsymbol{D}$ and $\boldsymbol{E}$, respectively. $\boldsymbol{G}$, Example of an efferent growth cone trailing after the afferent fibers (anterior posterior axis indicated by arrow). $\boldsymbol{H}$, Corresponding afferent fibers for the same image shown in $\boldsymbol{G}(2 \mathrm{dpf}) . \boldsymbol{I}, \boldsymbol{I} \boldsymbol{I}^{\prime}, 0$ verlays of $\boldsymbol{G}$ and $\boldsymbol{H}$, respectively. Scale bar: A-C', $20 \mu \mathrm{m} ; \boldsymbol{D}-\boldsymbol{F}^{\prime}, 5 \mu \mathrm{m} ; \boldsymbol{G}-\boldsymbol{I}^{\prime}, 30 \mu \mathrm{m}$.

cilitatory, perhaps neuroprotective role for DA in the cochlea (Lendvai et al., 2011). Pharmacological destruction of dopaminergic neurons decreases CAP amplitude in response to louder sounds in higher frequency ranges (Le Prell et al., 2005). In addition, D1-like receptor agonists increase CAP amplitude (Niu and Canlon, 2006), and antagonists decrease it (Ruel et al., 2001; Niu and Canlon, 2006). However, application of DA decreases sodium channel currents in afferent fibers in guinea pigs, thereby depressing the spike rate (Oestreicher et al., 1997; ValdésBaizabal et al., 2015) and D2/3R agonists have been reported to decrease CAP amplitudes (d'Aldin et al., 1995). Furthermore, in mice the deletion of D1R slightly decreases the threshold for the auditory brainstem response (ABR), whereas deletion of D2R receptors slightly increases ABR threshold (Maison et al., 2012). In light of these conflicting studies, the response to dopaminergic signaling in the inner ear is not clear and may be confounded by the presence of multiple receptor subtypes and target cells.

To gain a better understanding of how dopaminergic signaling modulates the activity of the sensory epithelium, we sought to characterize the receptor type, site of action, and physiological effects of DA on a tractable and intact preparation, the zebrafish lateral-line organ. The lateral-line organ senses hydrodynamic information, which is crucial for orientation to water currents, predator avoidance, prey detection, and schooling (for review, see Bleckmann and Zelick, 2009). In larval zebrafish, retrograde labeling combined with tyrosine hydroxylase (TH) immunohistochemistry localized dopaminergic efferent cell bodies to a single nucleus in the hypothalamus (Metcalfe et al., 1985; Bricaud et al., 2001). These experiments showed that TH-positive fibers in- nervate lateral-line neuromasts: the superficial sensory patches of hair cells and supporting cells of the lateral-line organ. To further investigate dopaminergic signaling in the lateral-line organ, we undertook a multipronged approach, using confocal microscopy of transgenic zebrafish and immunohistochemistry, electrophysiology, and ratiometric calcium imaging. Here we demonstrate that farprojecting dopaminergic neurons innervate lateral-line neuromasts early in development, and release DA in a paracrine fashion to activate D1Rs located at ribbon synapses in hair cells. Further, we show that D1R activation results in increased extracellular potentials of hair cells and an increase in intracellular calcium that requires the Cav1.3a calcium channel. Collectively, our results suggest that DA acts directly on hair cells, and our study provides insight into a molecular mechanism underlying DA signaling in the lateral-line organ.

\section{Materials and Methods}

Fish strains and lines. All experimental procedures were conducted according to the policies of the Institutional Animal Care and Use Committee of Oregon Health and Science University. The stable transgenic lines $\operatorname{Tg}(m y o 6 b$ : tdTomato) and $\mathrm{Tg}$ (neurod:tdTomato) were generated by injecting a construct based on the Tol2/Gateway system (Kwan et al., 2007) or the

Meganuclease system (Grabher et al., 2004) that contained a $6 \mathrm{~kb}$ minimal promoter of myo6b (Obholzer et al., 2008) driving expression of tdTomato specifically in hair cells or a $5 \mathrm{~kb}$ minimal promoter of neurod driving expression in the cranial ganglia. The $\mathrm{Tg}(\mathrm{slc} 6 a 3: E G P F)$ line was obtained from Marc Ekker (Xi et al., 2011). Wild-type and transgenic larvae were maintained in both Tübingen and Top Long Fin strains. Larvae were kept at $28.5^{\circ} \mathrm{C}$ in the dark in E3 medium during development and were of indeterminate sex at the stages used for our experiments ( $1-6 \mathrm{~d}$ post-fertilization [dpf]).

Pharmacological reagents. SCH-23390 (Sigma-Aldrich), isradipine (Sigma-Aldrich), and SKF-38393 (Tocris Bioscience) were diluted into E3 medium with $0.1 \%$ DMSO (Sigma-Aldrich) and used at the concentrations indicated in the text.

RT-PCR of sensory epithelia. Total RNA isolated from ear tissue (adult utricles and saccules) was used to synthesize cDNA with EcoDry Premix (Clontech Laboratories). We also synthesized cDNA from RNA isolated from whole larvae (5 dpf) or neuromasts. Neuromasts were extracted from the head and trunk of wild-type larvae by a suction pipette and aspirated into cold lysis buffer from Cells-to-cDNA kit II (Ambion). First-strand cDNA synthesis was performed using Sprint-RT CompleteOligo(dT) 18 kit (Clontech Laboratories). cDNAs were amplified by PCR using ChoiceTaq Blue Master Mix (Denville Scientific) with primers pairs targeting the following: $d r d 1 a$ (167F CTAAGGACTCATGACAC CCCC, 167R CAGTCACACCTCAGGTAGCAT), drd1b (169F GACG GTGAACAAACTGCTGA, 169R CTTACACGTGAATCGGAGCA), $d r d 2 a$ (100F TGCCCAGTTACAGACATGGA, 100R AATTCCCACTGGACT TGACG), $d r d 2 b$ (232F TTAAGACCAACGGGGGTGTA, 232R TGGC CATTTTTCTCATCTCC), $d r d 3$ (134F AAGAAAGCCACGCAGATGTT, 134R GTGAAGGCGCTGTAGACCTC), $d r d 4 a$ (110F ATCAACGGCAGAGAGAGGAA, 110R TCGCAGAGAGCCCTCATAGT), $d r d 4 b$ (118F GAAGAGGGCGAAGATCAATG, 118R CAGAGCTCGAGTGGTGTGAA), gapdh (163F GATACACGGAGCACCAGGTT, 163R GCCATCAG- 
GTCACATACAC, $c$ dh23 (136F CAGTAGTTG CAGGCTCCACA, 136R TGGGCTGCTAACTC CAGATT) and $p c d h 15 a$ (155F ACGGATAGTG GTGAGGGACA, 155R CGTTTGGTCCGTC GTCAATG).

Immunohistochemistry. Two monoclonal antibodies were generated against two D1b peptides: KKEDDSGIKT and SMGNNASMES (Abmart) and used at 1:500 dilution. Rabbit polyclonal Vglut3 antibody (1:1000 dilution) was described by Obholzer et al. (2008), and rabbit polyclonal Ribeye a antibodies (1:2500) were described previously (Sheets et al., 2011). Mouse anti-synaptophysin antibodies were obtained from Synaptic Systems (1:1000 dilution).

Briefly, 5 dpf larvae were fixed in 4\% PFA (Sigma-Aldrich) and phosphate buffer for $4.5 \mathrm{~h}$ at $4^{\circ} \mathrm{C}$, permeabilized with ice-cold acetone for $5 \mathrm{~min}$, and blocked with $\mathrm{P} / \mathrm{B} / \mathrm{D}$-goat solution (PBS containing 1\% BSA, 1\% DMSO, and $2 \%$ goat serum) for $2 \mathrm{~h}$ at room temperature (care was taken to use fresh stocks of PFA and DMSO). To decrease background labeling, a preabsorption step was used: The D1b antibodies were incubated with larvae (fixed/permeabilized) for $2 \mathrm{~h}$ at $4^{\circ} \mathrm{C}$. The larvae incubated in blocking solution were then incubated with the preabsorbed primary antibodies in $\mathrm{P} / \mathrm{B} / \mathrm{D}$ overnight at $4^{\circ} \mathrm{C}$, washed several times in $\mathrm{P} / \mathrm{B} / \mathrm{D}$, and incubated in $\mathrm{P} / \mathrm{B} / \mathrm{D}$ with secondary antibodies (1:500) conjugated to AlexaFluor-488 (Invitrogen), DyLight 549 or DyLight 647 (Jackson ImmunoResearch Laboratories) overnight at $4^{\circ} \mathrm{C}$. When larvae were costained with other antibodies, primary antibodies were added sequentially with a wash cycle in between, and AlexaFluor-488 (Invitrogen), and DyLight 647 (Jackson ImmunoResearch Laboratories) secondary antibodies were used. Stained larvae were mounted in elvanol ( $13 \% \mathrm{w} / \mathrm{v}$ polyvinyl alcohol, $33 \% \mathrm{w} / \mathrm{v}$ glycerol, $1 \% \mathrm{w} / \mathrm{v}$ DABCO $(1,4$ diazobicylo $[2,2,2]$ octane) in $0.2 \mathrm{M}$ Tris, $\mathrm{pH}$ 8.5; J.T. Baker). Images through the $z$ plane were collected with Zeiss Axiovert ImagerM.1 microscope with an LSM700 confocal scanhead, Axiocam MrM camera, and oil-immersion Zeiss Plan Apochromat $63 \times / 1.4 \mathrm{NA}$ objective; 488 and $639 \mathrm{~nm}$ laser lines were used for excitation, and laser intensities were adjusted to minimize photobleaching.

For blocking experiments, the same protocol was used with the following modifications: an additional step of preincubating the primary monoclonal Drd1b with $100 \mu \mathrm{M}$ peptide antigen (KKEDDSGIKT or SMGNNASMES) in P/B/D overnight at $4^{\circ} \mathrm{C}$, which was then followed by the preabsorption step and then staining. Larvae were costained with rabbit Ribeye a (1:2500) antibodies for $4.5 \mathrm{~h}$ at $4^{\circ} \mathrm{C}$. The secondary antibodies $(1: 500)$ were conjugated to AlexaFluor488 (Invitrogen) or DyLight 647 (Jackson ImmunoResearch Laboratories). Labeled larvae were mounted in $1 \%$ low melting point agarose (Invitrogen). The water-immersion Zeiss Plan Apochromat $63 \times / 1.4 \mathrm{NA}$ objective was used to collect images.

Live imaging of transgenic fish. Embryos and larvae were anesthetized with $0.01 \%$ tricaine (MS-222; Sigma) and embedded in $1.5 \%$ low melting point agarose containing $0.01 \%$ tricaine and imaged using the same microscope described above using a $10 \times$ or a $63 \times / 0.95 \mathrm{~A}$ water-immersion lens.

Labeling with FM1-43 vital dye. For each concentration of SCH23390, larvae ( $5 \mathrm{dpf}$ ) were exposed to drug for $10 \mathrm{~min}$ and then briefly
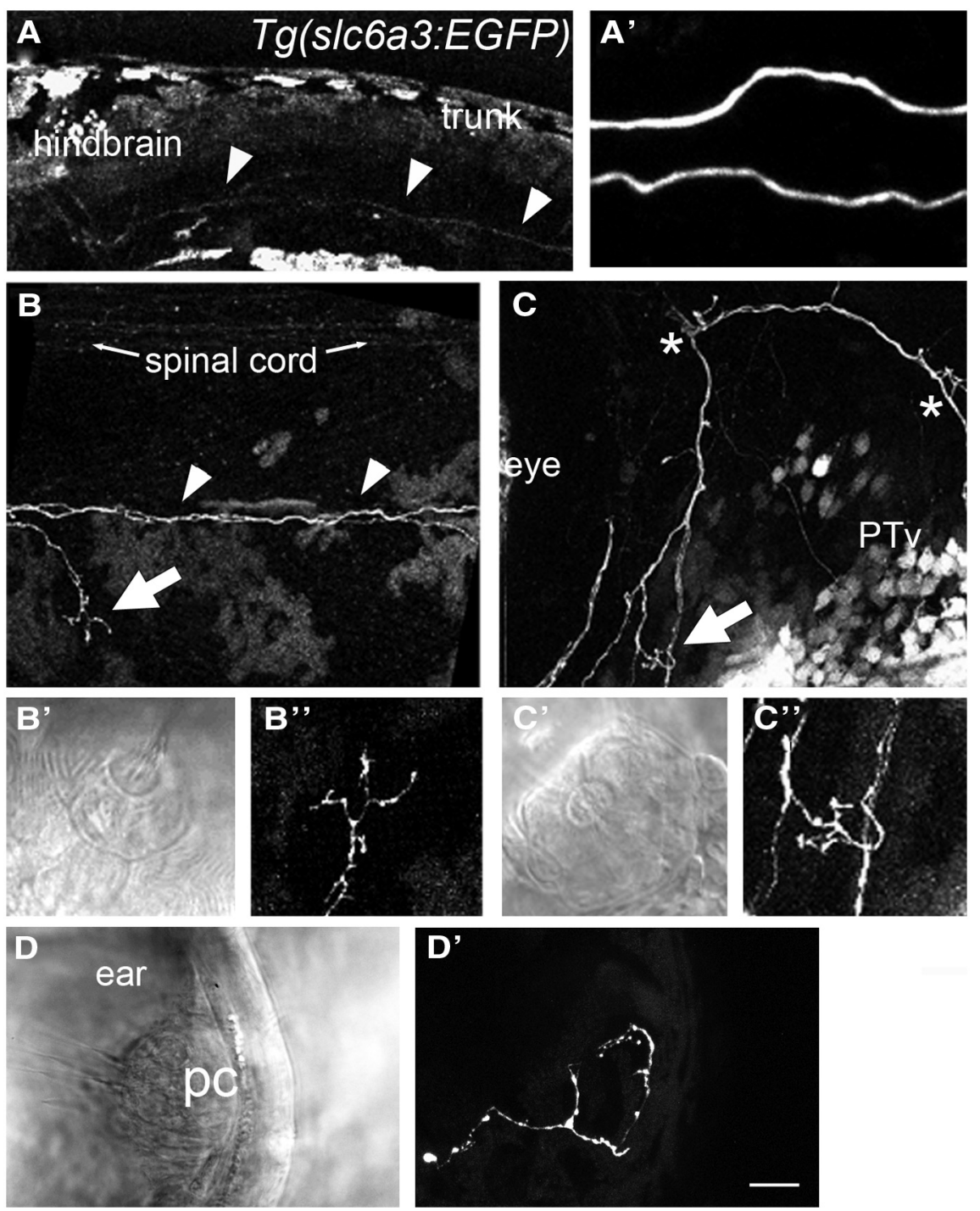

Figure 2. Dopaminergic innervation at larval stages suggests that modulation by DA is global. $A, 0$ verview of the GFP signal in the head of a Tg(slc6a3:EGFP) larva (5 dpf). Autofluorescence of pigment cells is apparent in the skin and swim bladder. Arrowheads erior neuromast (arrow). Arrowheads indicate descending fibers. Additional GFP-labeled fibers are visible in the spinal cord.

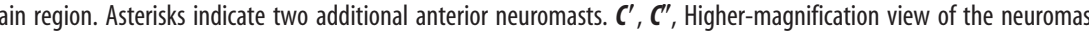
indicated by the arrow in $C . \boldsymbol{D}, \boldsymbol{D}^{\prime}$, Lateral view of a posterior crista within the inner ear of a $3 \mathrm{dpf}$ larva. PTv, ventral posterior tuberculum; pc, posterior crista. Scale bars: $\boldsymbol{A}, 50 \mu \mathrm{m} ; \boldsymbol{A}^{\prime}, 10 \mu \mathrm{m} ; \boldsymbol{B}, \boldsymbol{C}, 20 \mu \mathrm{m} ; \boldsymbol{B}^{\prime}-\boldsymbol{D}^{\prime}, 10 \mu \mathrm{m}$.

rinsed ( $5 \mathrm{~s}$ ) twice in E3. Larvae were then exposed to $3 \mu \mathrm{M}$ FM1-43 for $20 \mathrm{~s}$, rinsed twice, and then mounted for imaging as described above using a $63 \times 10.95 \mathrm{~A}$ water-immersion lens. The intensity of labeling of whole neuromasts was quantified by first drawing an ROI and then calculating mean pixel intensity using National Institutes of Health ImageJ software.

Microphonics recordings. Microphonic potentials were recorded as described previously (Trapani and Nicolson, 2010). Briefly, microphonic potentials were recorded from individual neuromasts by repeatedly deflecting hair cell kinocilia using a waterjet to deliver a $20 \mathrm{~Hz}, 200 \mathrm{~ms}$ sinusoidal stimulus. Drugs were bath applied. Microphonics that showed reversal of drug effect upon washout were included. Outliers were identified using Grubs test and excluded from datasets $(N=1$ outlier for both SKF-38393 and SCH-23390 data). Neuromasts contain 2 sets of hair cells that respond to deflection in opposing directions (Flock, 1965). Thus, 

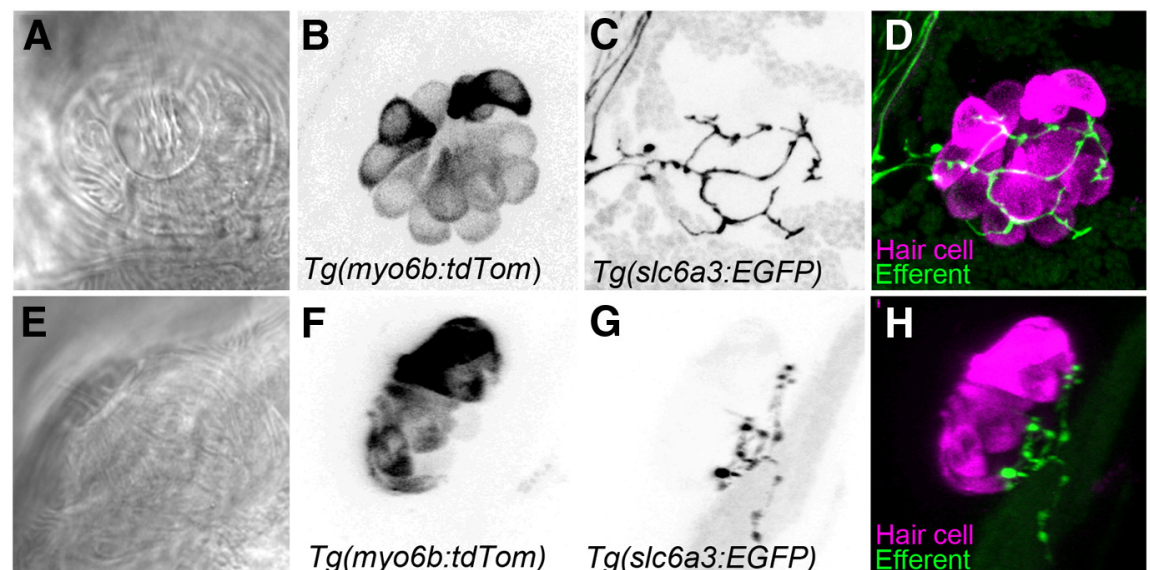

$\operatorname{Tg}$ (myo6b:tdTom)
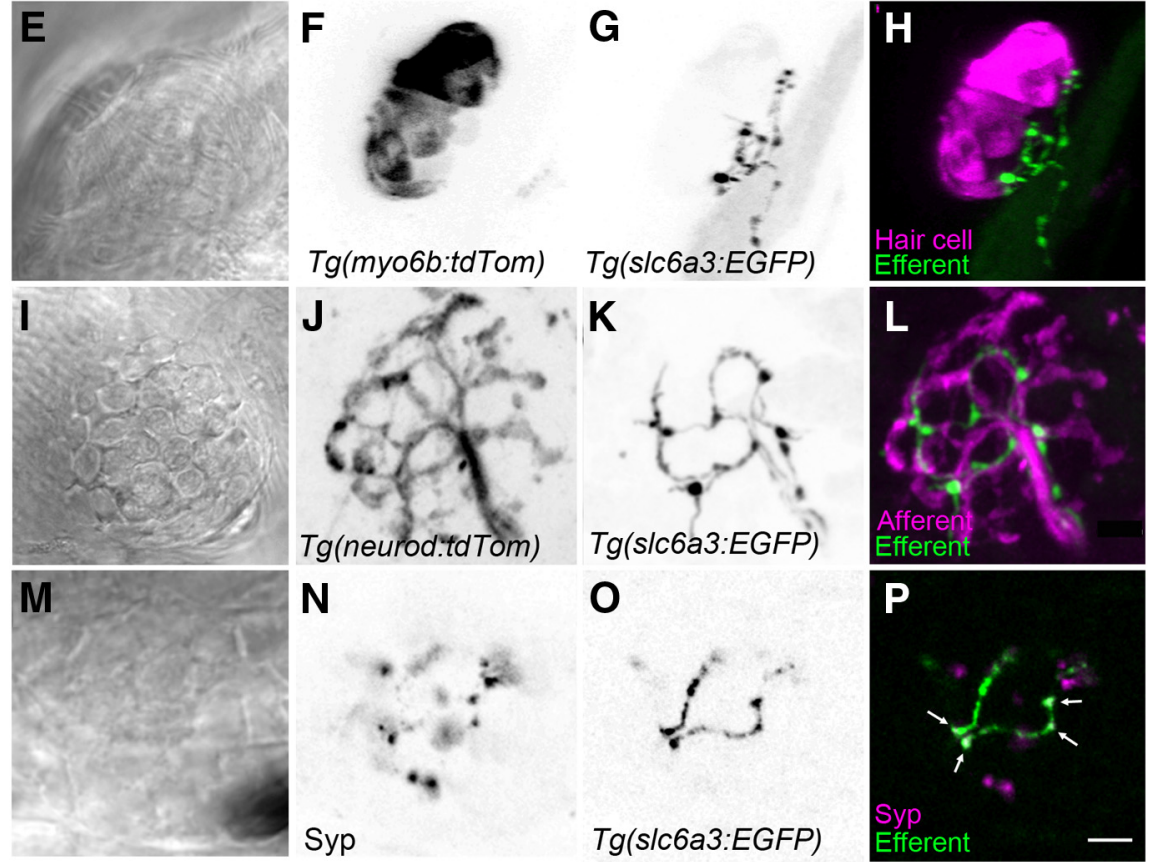

0

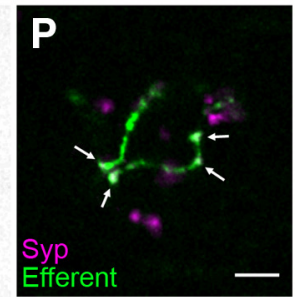

Tg(s/c6a3:EGFP) Efferent -

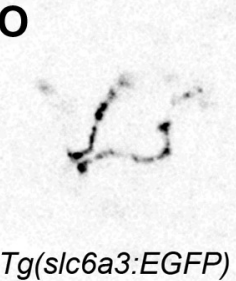

and standard fluorescence microscopy (Metcalfe et al., 1985; Bricaud et al., 2001). We sought to confirm this type of innervation and study its developmental time course using the recently generated transgenic line $\mathrm{Tg}($ slc6a3:EGFP), in which EGFP expression is driven by a $27 \mathrm{~kb}$ fragment containing the promoter of the DA transporter (slc6a3, previously known as dat) (Xi et al., 2011). The time course and pattern of afferent innervation of the posterior lateral-line (pLL) are well documented: afferent cell-bodies residing in the posterior lateral-line ganglion (pLLg) send out projections (part of the lateralline nerve) down the trunk of zebrafish as early as $1 \mathrm{dpf}$ (Metcalfe et al., 1985). Using live confocal imaging, we first probed whether dopaminergic efferent axons migrate along with afferent fibers. We crossed the $\mathrm{Tg}$ (slc6a3:EGFP) line to another line in which a subset of neurons, including afferent cells postsynaptic to hair cells, are labeled with tdTomato (Tg(neurod:tdTomato)). At $1 \mathrm{dpf}$, afferent fibers are clearly visible extending down each side of the zebrafish trunk from the pLLg (Fig. $1 B, C, C^{\prime}$ ). By contrast, no dopaminergic fibers are present within the developing lateral-line nerve, although some dopaminergic cell bodies are visible in the brain (Fig. $1 A, C$, arrowhead). In contrast to previous findings (Bricaud et al., 2001), we found that dopaminergic cells do not begin to extend their axons into the pLL nerve until $2 \mathrm{dpf}$ (Fig. $1 D, F, F^{\prime}$ ), at which point afferent neurons already show extensive innervation of neuromasts (Fig. 1 E, F). At 2 dpf, we observed the beginning of dopaminergic neurominergic fibers. $\boldsymbol{B}-\boldsymbol{D}, \boldsymbol{J}-\boldsymbol{L}$, Maximum projections. $\boldsymbol{F}-\boldsymbol{H}, 3 \mathrm{D}$ reconstructions of maximum projections. $\boldsymbol{A}, \boldsymbol{E}, \boldsymbol{I}, \boldsymbol{M}-\boldsymbol{P}$, Single optical slices. Scale bars: $\boldsymbol{A}-\boldsymbol{P}, 5 \mu \mathrm{m}$.

microphonics from the two sets of cells were analyzed separately. The peak amplitude of each of the 4 microphonic deflections for each set of hair cells was averaged.

SKF-38393: Hair cells were stimulated at $1 \mathrm{~Hz}$, and microphonic potentials were averaged every $90 \mathrm{~s}$. Data shown in Figure $6 B$ are averages of potentials $>1.5-3.0 \mathrm{~min}$ of exposure to $100 \mathrm{nM}$ SKF-38393, and of the 1.5-3.0 min following replacement of SKF-containing solution with control solution ("wash"). SCH-23390: Hair cells were stimulated at $0.5 \mathrm{~Hz}$ and microphonic potentials were averaged every $2 \mathrm{~min}$. Data shown in Figure $6 C$ are averages of 7-9 min of exposure to $10 \mu \mathrm{M} \mathrm{SCH}-23390$, and of the 5-7 min following replacement of SKF-containing solution with control solution ("wash").

Calcium imaging. Calcium transients in hair cells were imaged as described previously using a $\operatorname{Tg}(m y o 6 b: D 3 c p v)$ line (Kindt et al., 2012). Briefly, fish were exposed to $100 \mathrm{~nm}$ SKF-38393 or $10 \mu \mathrm{M} \mathrm{SCH}-23390$ for $3 \mathrm{~min}$, or $10 \mu \mathrm{M}$ isradipine for $15 \mathrm{~min}$ before imaging. Neuromasts were given 10 or $15 \mathrm{~min}$ to recover between successive steps of imaging. Data were graphed and analyzed with Graphpad Prism software. Two-tailed paired $t$ tests were performed to determine significance.

\section{Results}

Innervation of the lateral-line organ during development Previous studies of dopaminergic innervation of the zebrafish lateral line were executed in fixed tissue using lipophilic tracers mast innervations; short projections could be seen entering neuromast L1 (Fig. 1D), whereas dopaminergic growth cones had yet to reach the end of the tail (Fig. $1 G, I, I^{\prime}$ ). Thus, although dopaminergic axons do not migrate along with afferent fibers, they do follow the same tracts and begin to innervate pLL neuromasts after afferent fibers have reached their targets.

By $5 \mathrm{dpf}$, all of the neuromasts of the lateral-line show clear innervation by dopaminergic axons $(N>70$ larvae, at least 1 neuromast imaged per fish; every neuromast observed was innervated by dopaminergic axons). Interestingly, there appear to be only two individual axons that innervate each side of the lateral-line organ (Fig. $2 A, A^{\prime}$ ). This observation is consistent with earlier studies that found low numbers of neurons back-labeled from the pLL nerve (Metcalfe et al., 1985). Because every neuromast is innervated by dopaminergic axons (Fig. $2 B, B^{\prime \prime}$ ), the same fibers branch to innervate different neuromasts (Fig. $2 C-C^{\prime \prime}$ ). In addition to the pLL, we observed innervation of the inner ear (Fig. $2 D, D^{\prime}$ ). The low numbers of dopaminergic neurons along with the pattern of innervation suggest that modulation by DA is global in nature. 
A

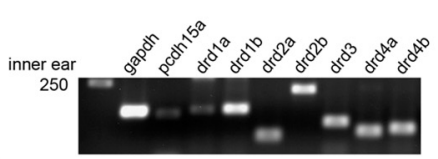

B
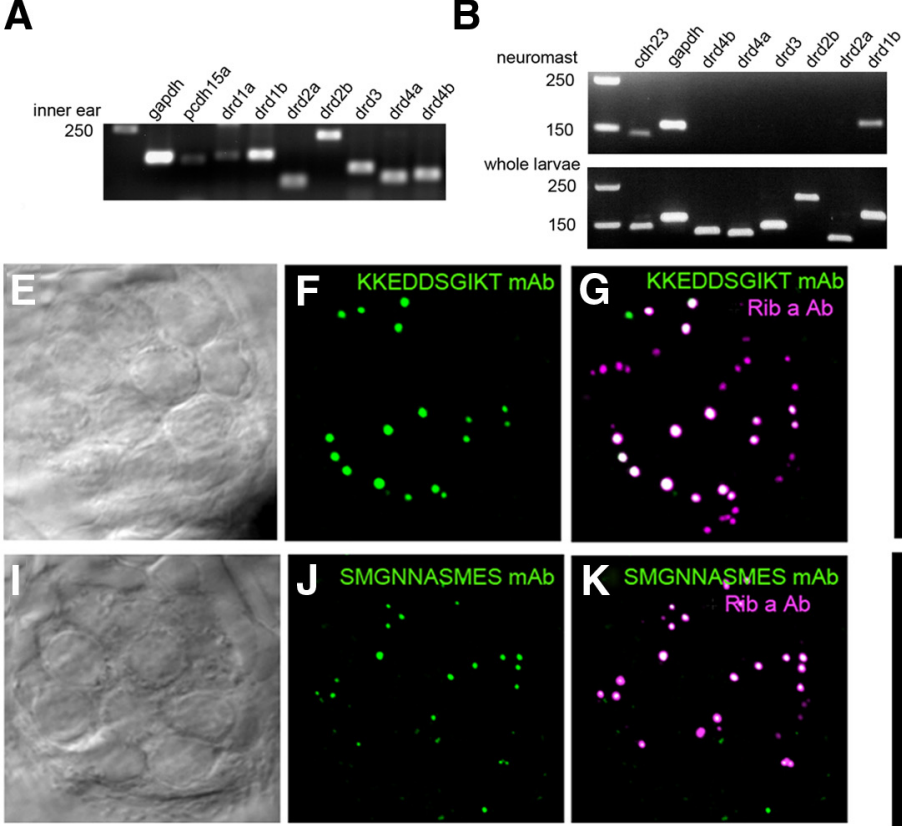
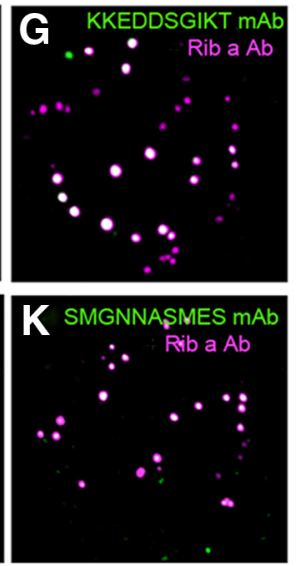

C
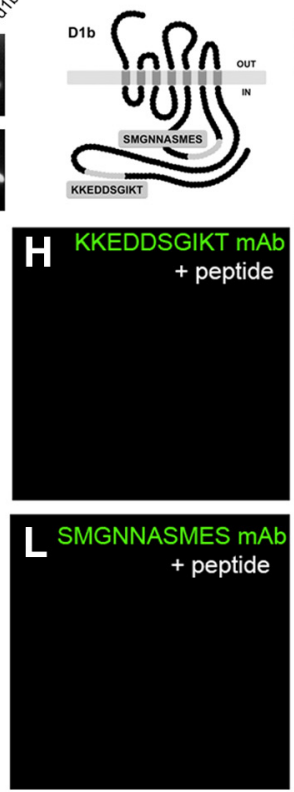
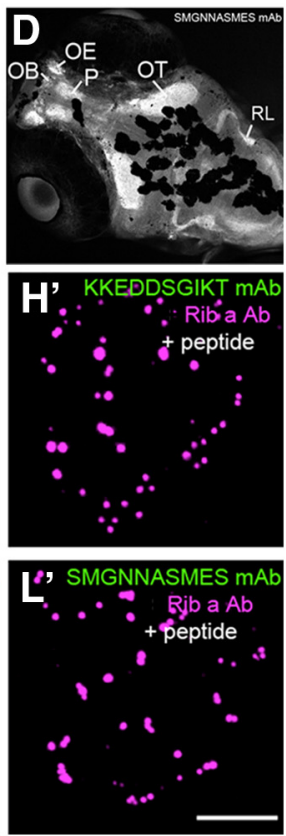

Figure 4. Expression of DA receptor subtypes in zebrafish. $A$, RT-PCR of drd genes from adult inner ear CDNA that includes both epithelial and neuronal cell types. $\boldsymbol{B}, \mathrm{RT}-\mathrm{PCR}$ of $d r d$ genes in neuromast and whole larval CDNA. DNA markers are present in the first lane, followed by positive controls ( gapdh and $p c d h 15 a$ or cdh23). C, Diagram of D1b protein depicting the location of the amino acid sequences used to generate monoclonal antibodies. $\boldsymbol{D}$, Immunolabel (SMGNNASMES mAb) of the head of a 5 dpf larva. The focal plane includes the dorsal region of the fish head, and signals are prominent within the forebrain, tectal, and hindbrain regions. Specific regions are indicated. Melanocytes partially occlude the labeling in deeper medial areas of the brain. $0 \mathrm{~B}, 0$ lfactory bulb; $\mathrm{OE}$, olfactory epithelium; $\mathrm{OT}$, optic tectum; P, pallium; RL, rhombic lip. E-F, I-J, Immunolabel of neuromast epithelia with D1b mAbs. DIC image (single optical plane) and corresponding immunofluorescence for KKEDDSGIKT $(\boldsymbol{E}, \boldsymbol{F})$ and SMGNNASMES mAbs $\left(\boldsymbol{I}, \boldsymbol{J}\right.$; maximum projections are shown). Colocalization with Ribeye a is shown in $\boldsymbol{G}, \boldsymbol{K}$. $\boldsymbol{H}, \boldsymbol{H}^{\prime}, \boldsymbol{L}, \boldsymbol{L}^{\prime}$, Peptide blocking experiments with KKEDDSGIKT and SMGNNASMES peptides using the corresponding D1b antibodies. Ribeye a antibody was included as a control in $\boldsymbol{H}^{\prime}, \boldsymbol{L}^{\prime}$. Scale bars: $\boldsymbol{D}, 75 \mu \mathrm{m} ; \boldsymbol{E}-\boldsymbol{L}^{\prime}, 5 \mu \mathrm{m}$.

\section{Cellular targets of dopaminergic fibers}

We next explored the question: what are the targets of the presynaptic dopaminergic efferents? There are multiple cell types in the neuromast that could be the target of dopaminergic efferents, including hair cells, supporting cells, afferents, and other types of efferents. To identify the postsynaptic partners of the dopaminergic efferents, we used both live in vivo imaging and immunohistochemistry. To determine whether dopaminergic efferents directly contact hair cells, we crossed the $\operatorname{Tg}($ slc6a3:EGFP) line to another transgenic line in which acousticolateralis hair cells are labeled with tdTomato (Tg(myo6b:tdTomato)) (Fig. 3A-H). We found no discernible, stereotyped pattern of efferent branching relative to hair-cell bodies, and the efferent neurons did not extend beneath all hair cells. Moreover, we were unable to detect obvious contacts between EGFPpositive efferent fibers and hair cells (Fig. $3 E-H$ ). The dopaminergic fibers appear to lie within the lower portion of the epithelium, where supporting cells reside (Fig. $3 G$ ). These data suggest that there are no direct synaptic contacts between dopaminergic efferents and hair cells.

To determine whether dopaminergic efferents contact nearby afferent neurons, we again used $\mathrm{Tg}(\operatorname{slc} 6 a 3$ :EGFP) fish crossed with $\mathrm{Tg}$ (neuroD:tdTomato) fish. We found that, although the dopaminergic efferent axons follow the same general tract as afferents, the level of innervation is less extensive, and they do not appear to make direct contact with the afferent fibers (Fig. 3I-L). Finally, we assessed whether dopaminergic efferents synapse onto presynaptic terminals of other efferents by staining $\mathrm{Tg}(\mathrm{slc6a3}$ :EGFP) fish with an antibody against the presynaptic protein synaptophysin (Fig. $3 M-P$ ). We found that dopaminergic presynaptic varicosities do not clearly appose any other presynaptic efferent terminals.

Together, these data suggest that dopaminergic axons do not make traditional synaptic contacts with any of the major cell types within the neuromast. This finding is consistent with data in many regions of the brain, including the retina where DA is released in a tonic, paracrine fashion and regulates multiple aspects of vision like the circadian modulation of gain (Yujnovsky et al., 2006; Yu et al., 2007; Jackson et al., 2012; Mu et al., 2012).

\section{Expression of dopamine receptors and localization to ribbon synapses}

Because the above live imaging experiments did not clearly establish the postsynaptic target cell of DA, we sought to locate the DA receptors to identify the postsynaptic cell type. We first determined which DA receptors are expressed in the adult inner ear maculae by performing RT-PCR with cDNA derived from total RNA. We used primers specific for seven DA receptor genes: $d r d 1 a, d r d 1 b, d r d 2 a, d r d 2 b, d r d 3, d r d 4 a$, and $d r d 4 b$ (Fig. $4 A)$. The other $d r d$ zebrafish genes ( $d r d 5 a, d r d 5 b, d r d 6 a, d r d 6 b$, and $d r d 7$ ) were excluded from our analysis because of the lack of introns, which is potentially confounding due to the amplification of genomic DNA. Strong bands were observed for all of the genes using cDNA derived from the inner ear, with the exception of $d r d 1 a$, which produced a very weak band (Fig. $4 A$ ). We then performed RT-PCR of the genes that showed robust expression in the inner ear using neuromast cDNA. While PCR products for all six genes were detected in total cDNA from whole larvae ( 5 $\mathrm{dpf}$ ), we were only able to detect a band for $d r d 1 b$, which encodes the dopamine receptor D1b, using neuromast cDNA (Fig. 4B). These results are consistent with studies in other animals implicating D1R in auditory function (Ruel et al., 2001; Inoue et al., 2006; Niu and Canlon, 2006; Maison et al., 2012) but also suggest that, as in other species (Gil-Loyzaga et al., 1994; d'Aldin et al., 1995; Karadaghy et al., 1997; Ruel et al., 2001; Inoue et al., 2006; 


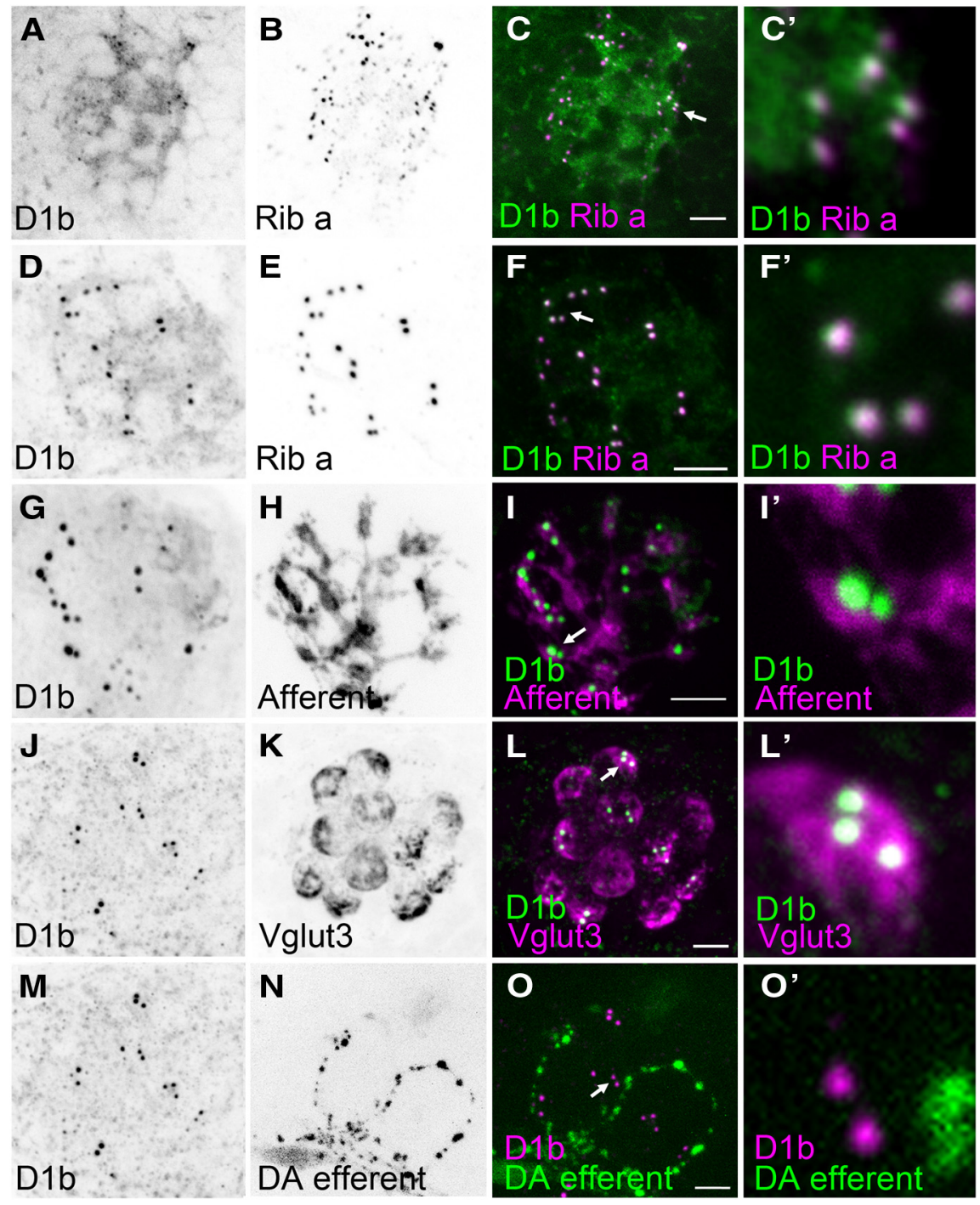

Figure 5. Subcellular localization of D1b at ribbon synapses in inner ear and lateral-line hair cells (5 dpf). Punctate pattern of D1b immunolabel in a macular endorgan (utricle) of the inner ear in $\boldsymbol{A}$, and lateral-line hair cells in $\boldsymbol{D}, \boldsymbol{G}, \boldsymbol{J}, \boldsymbol{M}$. $\boldsymbol{B}, \boldsymbol{E}$, Ribeye a immunolabel of hair cell ribbons. $\boldsymbol{C}, \boldsymbol{C}^{\prime}, \boldsymbol{F}, \boldsymbol{F}^{\prime}$, Overlap of D1b (green) and Ribeye a (magenta) staining in the inner ear and lateral-line organ. $\mathbf{G}-\boldsymbol{I}^{\prime}$, , D1b immunolabel (green) is juxtaposed to afferent fiber labeling (magenta). $\boldsymbol{J}-\boldsymbol{L}^{\prime}$, D1b puncta (green) are

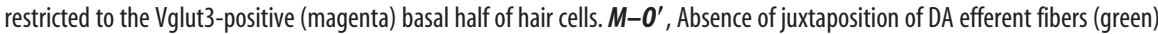
with D1b puncta (magenta). $\boldsymbol{A}-\boldsymbol{C}$, Single optical slices; all other images are maximum projections. KKEDDSGIKT mAb was used for $\mathbf{G}-\boldsymbol{I}^{\prime}$; all other panels are immunolabel obtained with SMGNNASMES mAb. Arrows indicate the D1b puncta shown in $\boldsymbol{C}^{\prime}, \boldsymbol{F}^{\prime}, \boldsymbol{I}^{\prime}, \boldsymbol{L}^{\prime}$, $\mathbf{O}^{\prime}$. Scale bars: $\boldsymbol{A}-\mathbf{0}, 5 \mu \mathrm{m} ; \boldsymbol{C}^{\prime}, \boldsymbol{F}^{\prime}, \boldsymbol{I}^{\prime}, \boldsymbol{L}^{\prime}, \mathbf{O}^{\prime}, 0.5 \mu \mathrm{m}$.

Maison et al., 2012), both D1 and D2 classes of DA receptors modulate the zebrafish inner ear.

Based on the presence of relatively high levels of transcripts for $d r d 1 b$ in both the inner ear and lateral-line organ, we generated monoclonal antibodies against two unique intracellular epitopes of D1b (Fig. 4C) (Li et al., 2007). The staining patterns with both monoclonal antibodies were indistinguishable; therefore, we used them interchangeably for our immunolabeling experiments. Catecholaminergic neurons have been previously described in the larval retina, forebrain, midbrain, and hindbrain (Ma, 2003; Kastenhuber et al., 2010; Tay et al., 2011; Schweitzer et al., 2012); therefore, we first examined immunolabel within these regions. We found that the pattern of D1b expression in the larval brain using confocal imaging was consistent with the welldocumented location of dopaminergic axons in the brain (e.g., Kastenhuber et al., 2010): staining was most prominent within the olfactory bulb, regions of the pallium, and included neuropil within the optic tectum and tracts within the hindbrain (Fig. 4D).

Next, we examined immunolabeling of D1b in the lateral-line organ. Labeling of the neuroepithelium revealed a highly punctate pattern that appeared to be within the hair-cell layer (Fig. $4 E, F, I, J)$. This pattern of labeling was remarkably similar to previously reported immunolabeling of synaptic ribbons in zebrafish hair cells (Sheets et al., 2011). Synaptic ribbons are a presynaptic specialization that is thought to facilitate neurotransmission (LoGiudice and Matthews, 2009). The main components of the synaptic ribbon in zebrafish are the proteins Ribeye $a$ and Ribeye $b$ (Wan et al., 2005; Sheets et al., 2011). To determine whether D1b is present at ribbon synapses, we costained larval fish with antibodies against D1b and a polyclonal antibody against Ribeye a. We found striking colocalization of the ribbon protein and D1b in lateral-line hair cells (Fig. $4 G, K$ ). In peptide blocking experiments for either D1b monoclonal antibody, we saw a strong reduction of the D1b signal, whereas Ribeye a immunolabeling was unaffected (Fig. $\left.4 H, H^{\prime}, L, L^{\prime}\right)$.

Consistent with our RT-PCR results, we also observed D1b immunolabel in the inner ear (Fig. 5A). In oblique views of ribbon synapses, we observed that the overlap of the two signals was not complete, suggesting that the D1b receptor is located within the active zone as predicted for a multispanning membrane protein in both the inner ear (Fig. $5 A-C^{\prime}$ ) and lateral-line hair cells (Fig. 5D-F'). This presynaptic location of D1b is supported by anti-D1b labeling in $\mathrm{Tg}$ (neuroD:tdTomato) fish (Fig. $5 G-I^{\prime}$ ), and costaining of D1b and the Vesicular Glutamate Transporter 3 (Vglut3), which is enriched at the basal end of hair cells (Obholzer et al., 2008) (Fig. 5J-L'). These experiments localize D1b to the base of hair cells (Fig. $5 L, L^{\prime}$ ), in direct apposition to afferent fibers (Fig. $5 I, I^{\prime}$ ). Finally, we stained $\mathrm{Tg}$ (slc6a3:EGFP) fish with D1b antibodies and found no obvious pattern of colocalization between dopaminergic axons and D1b protein (Fig. 5M-O'), consistent with the idea of paracrine DA transmission.

\section{DA modulation of hair-cell physiology}

The location of D1b at the hair-cell synaptic ribbon suggests that DA may modulate the output of hair cells. We hypothesized that inhibition or activation of D1b receptors would induce an inhibitory or stimulatory effect on hair-cell activity. To test this hypothesis, we examined several proxies for hair-cell activity: we tested FM1-43 labeling (Fig. 6), measured extracellular microphonics to detect the 

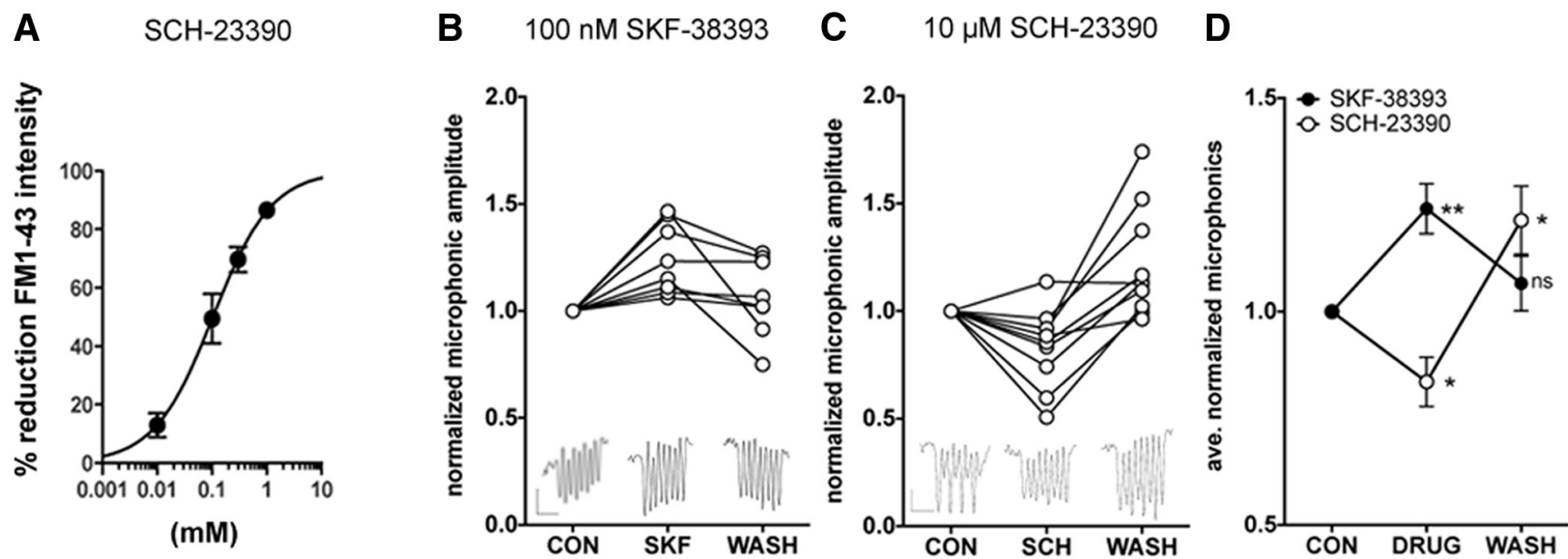

Figure 6. D1R modulators alter hair-cell activity. FM1-43 labeling of hair cells and microphonic potentials recorded from posterior lateral-line neuromasts were quantified to probe the effect of D1R activity on hair-cell function. For recordings, hair cells were stimulated with a $200 \mathrm{~ms}, 20 \mathrm{~Hz}$ sinusoidal wave. $A$, Percentage reduction of FM1- 43 labeling in response to four concentrations of SCH-23390 antagonist. $\boldsymbol{B}$, Normalized average microphonic amplitude for hair cells in control external solution (CON), in the presence of $100 \mathrm{~nm}$ D1R agonist SKF-38393 (SKF), and after replacement of SKF solution with control solution (WASH). Data from 7 fish and 8 sets of hair cells are shown $(N=8)$. C, As in $\boldsymbol{B}$, except in the presence of $10 \mu m$ D1R antagonist SCH-23390. Data from 7 fish and 10 sets of hair cells are shown $(N=10)$. $\boldsymbol{D}$, Average values from data in $\boldsymbol{B}, \boldsymbol{C}$. Significance between control and drug or wash was tested using one-way ANOVA with Dunnett's multiple-comparisons post test. ${ }^{*} p=0.01-0.05{ }^{* *} p=0.001-0.01$. ns, Not significant. $\boldsymbol{B}, \boldsymbol{C}$, Insets, Examples of averaged microphonics from a single neuromast. Calibration: $2 \mu V$ versus 100 ms.

overall change in receptor potential of hair cells (Fig. 6), and imaged intracellular calcium levels in hair cells, both in the presence and absence of D1R modulators (Fig. 7).

To assay whether the inhibition of D1 receptors leads to a change in hair-cell activity, we first exposed hair cells to the D1R antagonist SCH-23390 and then after two brief wash steps (5 s each), we added the vital dye FM1-43 (Fig. 6A). Labeling with FM1-43 is considered to be a proxy of open and active mechanotransduction (MET) channels (Gale et al., 2001). A reduction in labeling can indicate either direct block of the MET channel (Gale et al., 2001) or a reduction in driving force for cation flow into the hair cell through the mechanotransduction channels. We found that increasing concentrations of the D1R antagonist SCH-23390 decreased FM1-43 labeling in a dose-dependent manner (Fig. 6A). Given that the antagonist was not present during the labeling step, this result suggested that there was a reduced driving force for FM dye entry and labeling in the hair cells.

Next, we stimulated lateral-line neuromasts with a fluid jet and extracellularly recorded microphonic potentials, which represent the change in transepithelial membrane potential during concurrent activation of multiple hair cells (Flock, 1965; Trapani and Nicolson, 2010). Supporting our FM1-43 labeling data, we found that, when fish were exposed to the D1R antagonist SCH$23390(10 \mu \mathrm{M})$, the microphonic amplitude was reversibly and significantly decreased (Fig. 6C,D; average decrease of $16.4 \pm$ 5.8\%; control vs SCH-23390, $p \leq 0.05$ ). Furthermore, when hair cells were exposed to the D1R agonist SKF-38393 (100 nM), the microphonic amplitude was reversibly and significantly increased (Fig. $6 B, D$; average increase of $24.1 \pm 5.8 \%$; control vs SKF-38393, $p \leq 0.01)$. Together, these results suggest that D1b is tonically active and that D1b activation results in an increase in the transepithelial potentials measured by microphonic recordings. What might be the source for this effect on the receptor potential? Previously, we showed that a mutant zebrafish line that lacks the voltage-gated calcium channel Cav1.3a showed a decrease in receptor potential as measured with microphonic recordings (Sidi et al., 2004). D1R has been shown to couple to and activate voltage-gated calcium channels in multiple tissues, including the prefrontal cortex (Kisilevsky et al., 2008) and the retina (Esposti et al., 2013). Based on our data showing that D1R activation leads to an increase in hair-cell microphonic potentials, we hypothesized that D1R increases the activity of Cav1.3a channels. We therefore used calcium imaging to specifically measure changes in intracellular calcium concentrations that would result from the activation of Cav1.3a. We used a transgenic fish expressing the FRET-based calcium indicator cameleon specifically in hair cells (Kindt et al., 2012). We stimulated neuromasts using a fluid-jet and recorded the intracellular calcium levels as represented by the FRET ratio (Fig. 7). We found that, when fish were exposed to the D1R antagonist SCH-23390 (10 $\mu \mathrm{M})$, they showed a significant decrease in evoked calcium concentration (Fig. 7E; average maximum FRET ratios: control: $74.9 \pm 7.7$, SCH-23390: $57.3 \pm$ 5.5; control vs SCH-23390, $p=0.0058)$; and when they were exposed to D1R agonist SKF-38393 (100 nM), they showed a significant increase in calcium concentration (Fig. $7 A, B, E$; average maximum FRET ratios: control: $68.6 \pm 10.7$, SKF-38393: $96.9 \pm 12.1$; control vs SKF-38393, $p=0.0011$ ). These results support the notion that DA modulates calcium influx in hair cells.

Cav1.3 channels are located at the synaptic ribbon of hair cells where influx of calcium triggers neurotransmitter release (Brandt et al., 2003; Sidi et al., 2004). In zebrafish hair cells, Cav1.3a colocalizes with Ribeye proteins (Sheets et al., 2011, 2012), precisely where $\mathrm{D} 1 \mathrm{~b}$ is present (Fig. $5 F, F^{\prime}$ ). In addition, mutations in Cav1.3a substantially decrease mechanically evoked calcium influx, indicating that Cav1.3a makes a major contribution to the sum of calcium transients in lateral-line hair cells (Sheets et al., 2012). We therefore tested the role of Cav1.3a in D1R modulation of calcium levels. Cells pretreated with the Cav1.3 antagonist isradipine $(10 \mu \mathrm{M})$ showed a $38 \%$ decrease in mechanically evoked calcium levels (Fig. 7C, D, E; average maximum FRET ratios: control: $74.8 \pm 11.2$, isradipine: $46.5 \pm 8.5$, control vs isradipine, $p=0.0008$ ), consistent with previous findings (Sheets et al., 2012). When we challenged the isradipine-treated larvae with SKF-38393 (100 nM), we found that the D1R-mediated calcium increase was occluded (Fig. 7C,D,E; average maximum FRET ratio: isradipine + SKF-38393: $38.3 \pm 4.9$, isradipine vs isradipine + SKF-38393, $p=0.18$ ). These results support the hypothesis 
A

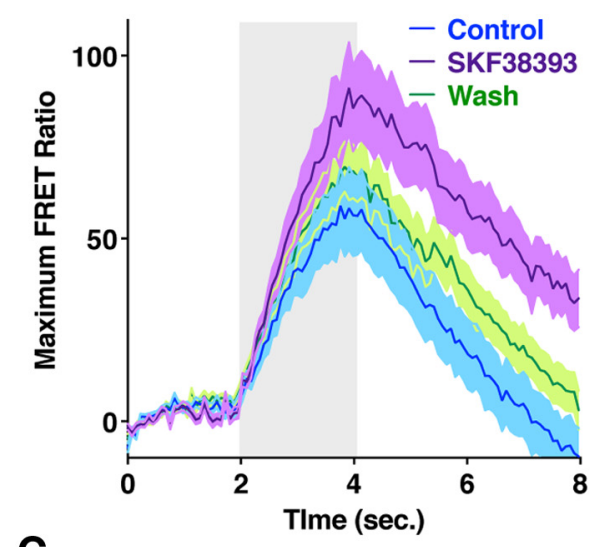

C

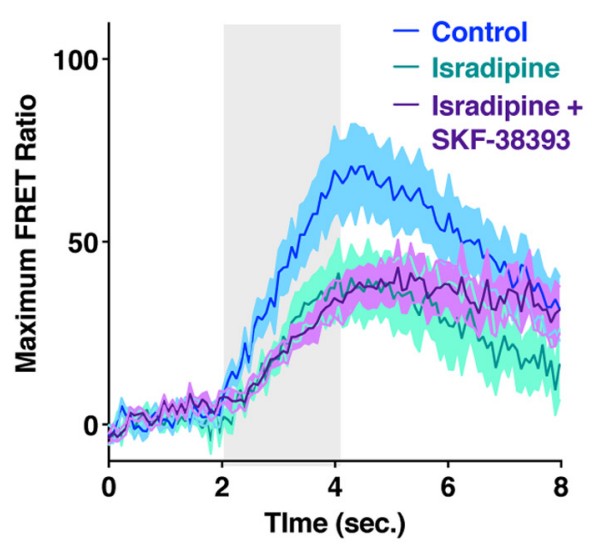

B

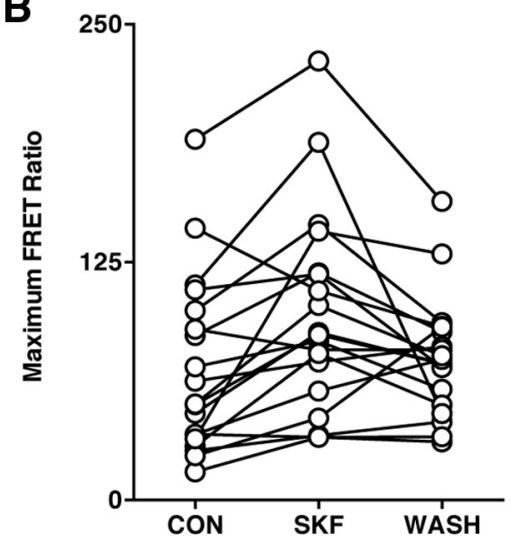

D

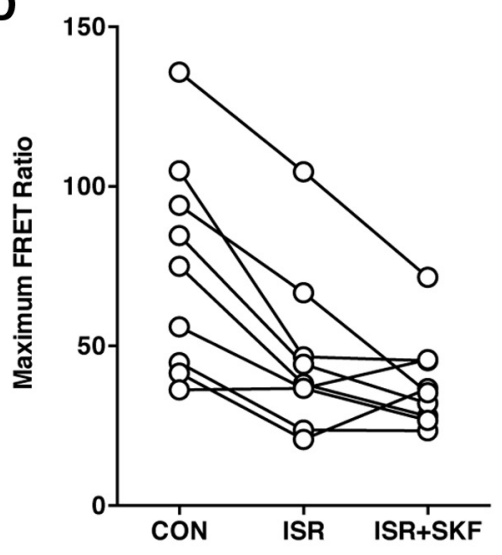

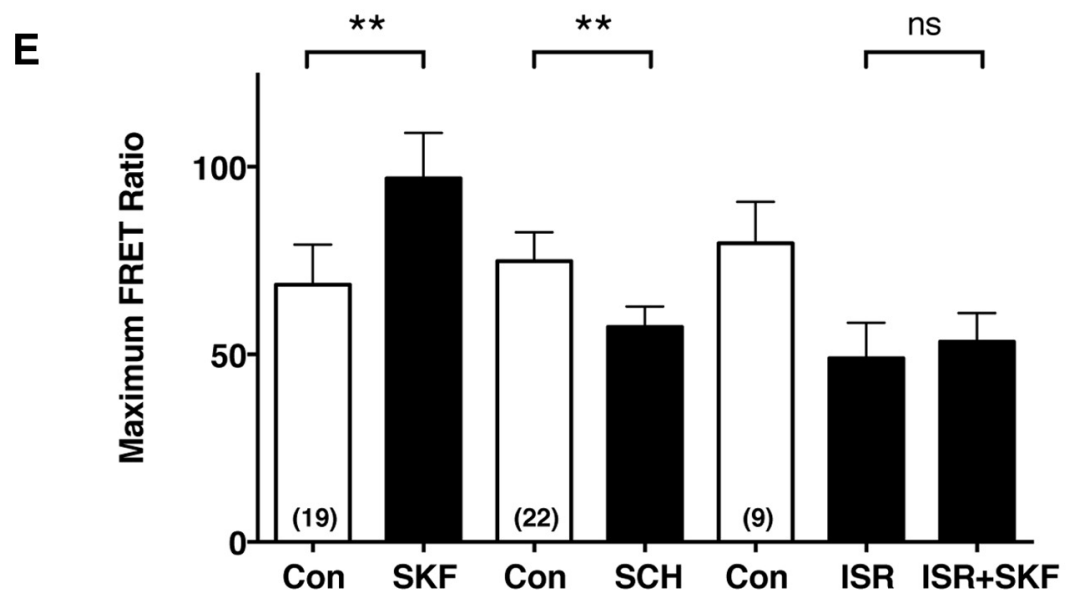

Figure 7. The increase in calcium transients elicited by the D1R agonist SKF-38393 is dependent upon Cav1.3a activity. Calcium transients were ratiometrically imaged in the hair cells of $T g$ (myo6b:D3) larvae. Hair cells were mechanically stimulated with a $2 \mathrm{~s}$

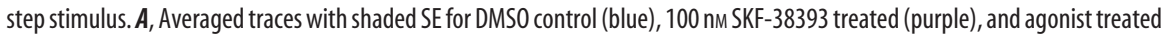
and washed (green) hair cells. Duration of the $2 \mathrm{~s}$ stimulus is indicated by gray area. B, Data from 19 individual hair cells. $\boldsymbol{C}$, Averaged traces with shaded SE for DMSO control (blue), $10 \mu \mathrm{m}$ isradipine treated (mint), and isradipine pretreated cells exposed to $100 \mathrm{~nm}$ SKF-38393 (purple). D, Data from 9 individual hair cells. $E$, Mean amplitudes (Maximum FRET Ratio) of evoked calcium transients in control and drug-treated hair cells. Con versus SKF, $p=0.0011$; Con versus $S C H, p=0.0058$; ISR versus ISR + SKF, $p=0.18$. ${ }^{* *} p<0.01$; ns, Not significant.

that $\mathrm{D} 1 \mathrm{R}$ activation leads to increases in intracellular calcium via the activity of presynaptic Cav1.3a channels.

\section{Discussion}

The role of DA as a neurotransmitter in the CNS and as a signaling molecule in peripheral organs is well established. Within the

inner ear, the function of dopaminergic signaling is less clear and appears to involve multiple targets and potentially different cAMP signaling pathways. Here we provide evidence for a molecular mechanism by which a D1R family member, $\mathrm{D} 1 \mathrm{~b}$, operates at the ribbon synapses in zebrafish hair cells. Our study suggests that paracrine signaling by dopaminergic efferents increases mechanically evoked responses in lateral-line hair cells. Potentiation of hair-cell activity by DA is achieved in part via D1b receptors that are tightly localized to presynaptic zones of hair cells, directly adjacent to synaptic ribbons. Activation of the D1b receptors at the ribbon synapse appears to modulate the activity of presynaptic Cav1.3a calcium channels. If Cav1.3a channels are acutely blocked, then the D1R agonist, SKF-38393, is unable to increase calcium signaling in hair cells.

Our finding that a D1-like family member is present in zebrafish hair cells is similar to observations made of rodent vestibular end organs, in which a portion of the D1A immunolabel was detected in the soma of hair cells (Drescher et al., 2010). The tight localization of zebrafish $\mathrm{D} 1 \mathrm{~b}$ in the active zone of afferent synapses of inner ear and lateral-line hair cells was, nevertheless, unexpected. In the lateralline organ of $T g($ slc6a3:EGFP) larvae, we found that EGFP-positive dopaminergic fibers were located within the supporting cell layer and not within the hair cell layer. Despite the possibility of synaptic contacts within the supporting cell layer, we were unable to detect D1b immunolabel in supporting cells or in other neurons that innervate the lateral-line neuroepithelium. This result is in contrast to D1R immunolabeling data reported for the organ of Corti (Maison et al., 2012) and in rodent vestibular organs that also display labeling within nerve fibers (Drescher et al., 2010). However, the presence of transcripts that encode both D1b and multiple D2R family members in the zebrafish inner ear suggests that DA signaling may involve other cellular targets, as reported for the trout saccule (Drescher et al., 2010). The lateral-line organ in larval zebrafish appears to be a relatively simple system that lacks D2-like receptors, although we were unable to determine whether D5-7 subtypes are present. The D1b receptors in lateral-line hair cells are positioned very close to dopaminergic fibers yet do not appear to be synaptically coupled, supporting the idea of local diffusion of DA, or paracrine signaling. Paracrine signaling by DA is a common feature of peripheral organs (Amenta et al., 2002; Goldstein, 2010), including the retina. The intermingling of D1b with the ribbon within 
the hair-cell presynapse is indicative of a role in direct modulation of synaptic transmission. Our data suggest that D1b may enhance the activity of Cav1.3a channels that have been shown to be present at ribbon synapses (Sheets et al., 2011, 2012).

Neurotransmitter-mediated G protein-coupled receptor modulation of calcium channels is a ubiquitous mechanism by which neurons control the synaptic activity of other neurons (Boehm and Kubista, 2002; Elmslie, 2003; Tedford and Zamponi, 2006). Gs-coupled receptors facilitate the activity of $\mathrm{Ca}_{\mathrm{V}} 1$ channels in multiple tissues: D1Rs and $\beta$-adrenergic receptors augment $\mathrm{Ca}_{\mathrm{V}} 1$ currents and neurotransmitter secretion in chromaffin cells and potentiate $\mathrm{Ca}_{\mathrm{V}} 1$ currents in cardiac cells (Bean et al., 1984; Artalejo et al., 1990; Carabelli et al., 2001, 2003). Moreover, interactions between DA receptors and calcium channels have been identified in neuronal tissues, including the prefrontal cortex, striatum, and retina (Surmeier et al., 1995; Kisilevsky et al., 2008; Esposti et al., 2013). In the rodent cortex and striatum, D1Rs selectively form complexes with $\mathrm{Ca}_{\mathrm{V}} 2.2$ channels and inhibit their activity (Kisilevsky et al., 2008). In the striatum, the effect of D1R modulators on $\mathrm{Ca}_{\mathrm{V}} 2.1$ and $\mathrm{Ca}_{\mathrm{V}} 2.2$ channels was varied: sometimes inhibition was seen, while other times potentiation was recorded (Surmeier et al., 1995). Our study suggests that D1R-calcium channel coupling also extends to sensory hair cells, in which there appears to be a signaling pathway between D1R and Cav1.3a that results in increased intracellular calcium responses to hair bundle deflection. This type of coupling is similar to the DA signaling observed in goldfish Mb1 bipolar cells in which D1Rs potentiate calcium currents (Esposti et al., 2013). Interestingly, the calcium channels that drive neurotransmission in bipolar cells are most likely $\mathrm{Ca}_{\mathrm{V}} 1.3$ (Logiudice et al., 2006), and bipolar cells also possess ribbon synapses (von Gersdorff et al., 1996). Thus, positive modulation by DA via $\mathrm{Ca}_{\mathrm{V}} 1.3$ channels may be a conserved feature of a subtype of ribbon synapses.

Although our study gives insight into the mechanism of dopaminergic signaling in hair cells, the biological function of dopaminergic modulation of hair-cell activity within the larval inner ear or lateral-line organ is not clear. In the aforementioned study of DA signaling in retinal bipolar cells, the efferent inputs originated from the olfactory system and are thought to modulate light sensitivity in the presence of olfactory cues (Esposti et al., 2013). Such modulation may enhance capture of prey or the ability to avoid predators by larval zebrafish. Other behaviors in teleost fish that appear to be modulated by catecholamines include social and reproductive behaviors (O'Connell and Hofmann, 2011; Goodson and Kingsbury, 2013; Petersen et al., 2013). In terms of auditory-related behaviors, studies of the plainfin midshipman fish offer some clues as to how auditory behavior may be modulated by catecholamines. In midshipman adults, the periventricular posterior tuberculum in the CNS has been corroborated as the site where catecholaminergic cell bodies project to several areas, including central auditory nuclei, the auditory neuroepithelium of the sacculus, and hindbrain nuclei that control vocal muscles (Forlano et al., 2014). Midshipman fish use vocalization for courtship, and modulation of catecholaminergic circuitry by male vocalizations suggests that auditory inputs drive efferent signaling (Petersen et al., 2013). Such efferent activity is potentially controlling phonotaxis of females to male mating calls and other social acoustic behaviors (Petersen et al., 2013; Forlano et al., 2014). Similar to the midshipman fish, the hypothalamic posterior tuberculum in zebrafish larvae was identified as the site of catecholaminergic cell bodies that inner- vate the lateral-line organ (Metcalfe et al., 1985). However, the inputs to these central neurons that are relevant for the function of the lateral-line organ have not been described. In larvae, we observed two descending axons that innervated all neuromasts of the trunk. Neuromasts on the head also appeared to be innervated by a low number of fibers. Our results suggest that dopaminergic modulation of hair cells is global and not tuned to individual sensory patches. While the purpose of tonic DA signaling in increasing the activity of hair cells of the developing larvae remains to be determined, we speculate that the potentially global upregulation or downregulation of hair-cell activity may be controlled in more of a hormonal fashion, such as by circadian rhythms as described for the visual system, or alternatively, DA signaling may be influenced by motor or sensory inputs.

\section{References}

Amenta F, Ricci A, Tayebati SK, Zaccheo D (2002) The peripheral dopaminergic system: morphological analysis, functional and clinical applications. Ital J Anat Embryol 107:145-167. Medline

Artalejo CR, Ariano MA, Perlman RL, Fox AP (1990) Activation of facilitation calcium channels in chromaffin cells by D1 dopamine receptors through a cAMP/protein kinase A-dependent mechanism. Nature 348: 239-242. CrossRef Medline

Bean BP, Nowycky MC, Tsien RW (1984) Beta-adrenergic modulation of calcium channels in frog ventricular heart cells. Nature 307:371-375. CrossRef Medline

Beaulieu JM, Gainetdinov RR (2011) The physiology, signaling, and pharmacology of dopamine receptors. Pharmacol Rev 63:182-217. CrossRef Medline

Bleckmann H, Zelick R (2009) Lateral-line system of fish. Integr Zool 4: 13-25. CrossRef Medline

Boehm S, Kubista H (2002) Fine tuning of sympathetic transmitter release via ionotropic and metabotropic presynaptic receptors. Pharmacol Rev 54:43-99. CrossRef Medline

Brandt A, Striessnig J, Moser T (2003) CaV1.3 channels are essential for development and presynaptic activity of cochlear inner hair cells. J Neurosci 23:10832-10840. Medline

Bricaud O, Chaar V, Dambly-Chaudière C, Ghysen A, Dambly-Chaudie C (2001) Early efferent innervation of the zebrafish lateral-line. J Comp Neurol 434:253-261. CrossRef Medline

Carabelli V, Hernández-Guijo JM, Baldelli P, Carbone E (2001) Direct autocrine inhibition and cAMP-dependent potentiation of single L-type $\mathrm{Ca}^{2+}$ channels in bovine chromaffin cells. J Physiol 532:73-90. CrossRef Medline

Carabelli V, Giancippoli A, Baldelli P, Carbone E, Artalejo AR (2003) Distinct potentiation of L-type currents and secretion by cAMP in rat chromaffin cells. Biophys J 85:1326-1337. CrossRef Medline

d'Aldin C, Puel JL, Leducq R, Crambes O, Eybalin M, Pujol R (1995) Effects of a dopaminergic agonist in the guinea pig cochlea. Hear Res 90:202-211. CrossRef Medline

Darrow KN, Simons EJ, Dodds L, Liberman MC (2006) Dopaminergic innervation of the mouse inner ear: evidence for a separate cytochemical group of cochlear efferent fibers. J Comp Neurol 498:403-414. CrossRef Medline

Drescher MJ, Cho WJ, Folbe AJ, Selvakumar D, Kewson DT, Abu-Hamdan MD, Oh CK, Ramakrishnan NA, Hatfield JS, Khan KM, Anne S, Harpool EC, Drescher DG (2010) An adenylyl cyclase signaling pathway predicts direct dopaminergic input to vestibular hair cells. Neuroscience 171: 1054-1074. CrossRef Medline

Elmslie KS (2003) Neurotransmitter modulation of neuronal calcium channels. J Bioenerg Biomembr 35:477-489. CrossRef Medline

Esposti F, Johnston J, Rosa JM, Leung KM, Lagnado L (2013) Olfactory stimulation selectively modulates the OFF pathway in the retina of zebrafish. Neuron 79:97-110. CrossRef Medline

Eybalin M, Charachon G, Renard N (1993) Dopaminergic lateral efferent innervation of the guinea-pig cochlea: immunoelectron microscopy of catecholamine-synthesizing enzymes and effect of 6-hydroxydopamine. Neuroscience 54:133-142. CrossRef Medline

Flock A (1965) Transducing mechanisms in the lateral-line canal organ receptors. Cold Spring Harb Symp Quant Biol 30:133-145. CrossRef Medline

Forlano PM, Kim SD, Krzyminska ZM, Sisneros JA (2014) Catecholamin- 
ergic connectivity to the inner ear, central auditory, and vocal motor circuitry in the plainfin midshipman fish porichthys notatus. J Comp Neurol 522:2887-2927. CrossRef Medline

Gale JE, Marcotti W, Kennedy HJ, Kros CJ, Richardson GP (2001) FM1-43 dye behaves as a permeant blocker of the hair-cell mechanotransducer channel. J Neurosci 21:7013-7025. Medline

Gil-Loyzaga P, Parés-Herbute N (1989) HPLC detection of dopamine and noradrenaline in the cochlea of adult and developing rats. Brain Res Dev Brain Res 48:157-160. CrossRef Medline

Gil-Loyzaga P, Vicente-Torres MA, Fernández-Mateos P, Arce A, Esquifino A (1994) Piribedil affects dopamine turnover in cochleas stimulated by white noise. Hear Res 79:178-182. CrossRef Medline

Goldstein DS (2010) Catecholamines 101. Clin Auton Res 20:331-352. CrossRef Medline

Goodson JL, Kingsbury MA (2013) What's in a name? Considerations of homologies and nomenclature for vertebrate social behavior networks. Horm Behav 64:103-112. CrossRef Medline

Grabher C, Joly JS, Wittbrodt J (2004) The zebrafish: genetics, genomics, and informatics. Amsterdam: Elsevier.

Inoue T, Matsubara A, Maruya S, Yamamoto Y, Namba A, Sasaki A, Shinkawa $\mathrm{H}$ (2006) Localization of dopamine receptor subtypes in the rat spiral ganglion. Neurosci Lett 399:226-229. CrossRef Medline

Jackson CR, Ruan GX, Aseem F, Abey J, Gamble K, Stanwood G, Palmiter RD, Iuvone PM, McMahon DG (2012) Retinal dopamine mediates multiple dimensions of light-adapted vision. J Neurosci 32:9359-9368. CrossRef Medline

Karadaghy AA, Lasak JM, Chomchai JS, Khan KM, Drescher MJ, Drescher DG (1997) Quantitative analysis of dopamine receptor messages in the mouse cochlea. Brain Res Mol Brain Res 44:151-156. CrossRef Medline

Kastenhuber E, Kratochwil CF, Ryu S, Schweitzer J, Driever W (2010) Genetic dissection of dopaminergic and noradrenergic contributions to catecholaminergic tracts in early larval zebrafish. J Comp Neurol 518: 439-458. CrossRef Medline

Kindt KS, Finch G, Nicolson T (2012) Kinocilia mediate mechanosensitivity in developing zebrafish hair cells. Dev Cell 23:329-341. CrossRef Medline

Kisilevsky AE, Mulligan SJ, Altier C, Iftinca MC, Varela D, Tai C, Chen L, Hameed S, Hamid J, Macvicar BA, Zamponi GW (2008) D1 receptors physically interact with $\mathrm{N}$-type calcium channels to regulate channel distribution and dendritic calcium entry. Neuron 58:557-570. CrossRef Medline

Kwan KM, Fujimoto E, Grabher C, Mangum BD, Hardy ME, Campbell DS, Parant JM, Yost HJ, Kanki JP, Chien CB (2007) The Tol2kit: a multisite gateway-based construction kit for Tol2 transposon transgenesis constructs. Dev Dyn 236:3088-3099. CrossRef Medline

Lendvai B, Halmos GB, Polony G, Kapocsi J, Horváth T, Aller M, Sylvester Vizi E, Zelles T (2011) Chemical neuroprotection in the cochlea: the modulation of dopamine release from lateral olivocochlear efferents. Neurochem Int 59:150-158. CrossRef Medline

Le Prell CG, Halsey K, Hughes LF, Dolan DF, Bledsoe SC Jr (2005) Disruption of lateral olivocochlear neurons via a dopaminergic neurotoxin depresses sound-evoked auditory nerve activity. J Assoc Res Otolaryngol 6:48-62. CrossRef Medline

Li P, Shah S, Huang L, Carr AL, Gao Y, Thisse C, Thisse B, Li L (2007) Cloning and spatial and temporal expression of the zebrafish dopamine D1 receptor. Dev Dyn 236:1339-1346. CrossRef Medline

LoGiudice L, Matthews G (2009) The role of ribbons at sensory synapses. Neuroscientist 15:380-391. CrossRef Medline

Logiudice L, Henry D, Matthews G (2006) Identification of calcium channel alphal subunit mRNA expressed in retinal bipolar neurons. Mol Vis 12: 184-189. Medline

Ma PM (2003) Catecholaminergic systems in the zebrafish: IV. Organization and projection pattern of dopaminergic neurons in the diencephalon. J Comp Neurol 460:13-37. CrossRef Medline

Maison SF, Liu XP, Eatock RA, Sibley DR, Grandy DK, Liberman MC (2012) Dopaminergic signaling in the cochlea: receptor expression patterns and deletion phenotypes. J Neurosci 32:344-355. CrossRef Medline

Metcalfe WK, Kimmel CB, Schabtach E (1985) Anatomy of the posterior lateral-line system in young larvae of the zebrafish. J Comp Neurol 233: 377-389. CrossRef Medline

Mu Y, Li XQ, Zhang B, Du JL (2012) Visual input modulates audiomotor function via hypothalamic dopaminergic neurons through a cooperative mechanism. Neuron 75:688-699. CrossRef Medline

Niu X, Canlon B (2006) The signal transduction pathway for the dopamine D1 receptor in the guinea-pig cochlea. Neuroscience 137:981-990. CrossRef Medline

Obholzer N, Wolfson S, Trapani JG, Mo W, Nechiporuk A, Busch-Nentwich E, Seiler C, Sidi S, Söllner C, Duncan RN, Boehland A, Nicolson T (2008) Vesicular glutamate transporter 3 is required for synaptic transmission in zebrafish hair cells. J Neurosci 28:2110-2118. CrossRef Medline

O'Connell LA, Hofmann HA (2011) The Vertebrate mesolimbic reward system and social behavior network: a comparative synthesis. J Comp Neurol 519:3599-3639. CrossRef Medline

Oestreicher E, Arnold W, Ehrenberger K, Felix D (1997) Dopamine regulates the glutamatergic inner hair-cell activity in guinea pigs. Hear Res 107:46-52. CrossRef Medline

Petersen CL, Timothy M, Kim DS, Bhandiwad AA, Mohr RA, Sisneros JA, Forlano PM (2013) Exposure to advertisement calls of reproductive competitors activates vocal-acoustic and catecholaminergic neurons in the plainfin midshipman fish, Porichthys notatus. PLoS One 8:e70474. CrossRef Medline

Ruel J, Nouvian R, Gervais d'Aldin C, Pujol R, Eybalin M, Puel JL (2001) Dopamine inhibition of auditory nerve activity in the adult mammalian cochlea. Eur J Neurosci 14:977-986. CrossRef Medline

Schofield BR (2011) Central descending auditory pathways. In: Auditory and vestibular efferents (Ryugo DK, Fay RR, Popper A, eds.), pp 261-290. New York: Springer-Verlag.

Schweitzer J, Lohr H, Filippi A, Driever W (2012) Dopaminergic and noradrenergic circuit development in zebrafish. Dev Neurobiol 72:256-268. CrossRef Medline

Sheets L, Trapani JG, Mo W, Obholzer N, Nicolson T (2011) Ribeye is required for presynaptic $\mathrm{CaV} 1.3 \mathrm{a}$ channel localization and afferent innervation of sensory hair cells. Development 138:1309-1319. CrossRef Medline

Sheets L, Kindt KS, Nicolson T (2012) Presynaptic CaV1.3 channels regulate synaptic ribbon size and are required for synaptic maintenance in sensory hair cells. J Neurosci 32:17273-17286. CrossRef Medline

Sidi S, Busch-Nentwich E, Friedrich R, Schoenberger U, Nicolson T (2004) Gemini encodes a zebrafish L-type calcium channel that localizes at sensory hair cell ribbon synapses. J Neurosci 24:4213-4223. CrossRef Medline

Surmeier DJ, Bargas J, Hemmings HC Jr, Nairn AC, Greengard P (1995) Modulation of calcium currents by a D1 dopaminergic protein kinase/ phosphatase cascade in rat neostriatal neurons. Neuron 14:385-397. CrossRef Medline

Tay TL, Ronneberger O, Ryu S, Nitschke R, Driever W (2011) Comprehensive catecholaminergic projectome analysis reveals single-neuron integration of zebrafish ascending and descending dopaminergic systems. Nat Commun 2:171. CrossRef Medline

Tedford HW, Zamponi GW (2006) Direct G protein modulation of Cav2 calcium channels. Pharmacol Rev 58:837-862. CrossRef Medline

Trapani JG, Nicolson T (2010) Physiological recordings from zebrafish lateral-line hair cells and afferent neurons, Ed 3. Amsterdam: Elsevier.

Valdés-Baizabal C, Soto E, Vega R (2015) Dopaminergic modulation of the voltage-gated sodium current in the cochlear afferent neurons of the rat. PLoS One 10:e0120808. CrossRef Medline

von Gersdorff H, Vardi E, Matthews G, Sterling P (1996) Evidence that vesicles on the synaptic ribbon of retinal bipolar neurons can be rapidly released. Neuron 16:1221-1227. CrossRef Medline

Wan L, Almers W, Chen W (2005) Two ribeye genes in teleosts: the role of ribeye in ribbon formation and bipolar cell development. J Neurosci 25: 941-949. CrossRef Medline

Xi Y, Yu M, Godoy R, Hatch G, Poitras L, Ekker M (2011) Transgenic zebrafish expressing green fluorescent protein in dopaminergic neurons of the ventral diencephalon. Dev Dyn 240:2539-2547. CrossRef Medline

Yu CJ, Gao Y, Li P, Li L (2007) Synchronizing multiphasic circadian rhythms of rhodopsin promoter expression in rod photoreceptor cells. J Exp Biol 210:676-684. CrossRef Medline

Yujnovsky I, Hirayama J, Doi M, Borrelli E, Sassone-Corsi P (2006) Signaling mediated by the dopamine D2 receptor potentiates circadian regulation by CLOCK:BMAL1. Proc Natl Acad Sci U S A 103:6386-6391. CrossRef Medline 